\title{
5. Sınıf Öğrencilerinin “Canlılar Dünyasını Gezelim ve Tanıyalım” Ünitesi ile İlgili Kavram Yanılgıları*
}

\section{Evşen AYMEN PEKER ${ }^{* * *}$, Erol TAŞ P̧** $^{* *}$}

Öz: 5. sınıf öğrencilerinin “Canlılar Dünyasını Gezelim ve Tanıyalım” ünitesi ile ilgili kavram yanılgılarını belirlemek amacıyla gerçekleştirilen çalışma, 2014-2015 eğitim öğretim yılında yürütülmüştür. $\mathrm{Bu}$ çalışmaya üç farklı okuldan 226 öğrenci katılmıştır. Karma araştırma yöntemlerinin uygulandığı çalışmada; nitel veriler yarı yapılandırılmış görüşmelerden, nicel veriler ise üç aşamalı kavram tanı testinden elde edilmiştir. Kavram tanı testinden elde edilen veriler Microsoft Excel'de hazırlanan uygulama ile değerlendirilmiştir. Böylece, öğrencilerin hem kavram yanılgıları hem de eksik bilgiye sahip oldukları konular belirlenmiştir. Araştırma sonucunda, tanı testindeki yirmi üç sorudan on ikisi ile ilişkili toplam kırk kavram yanılgısı tespit edilmiştir. Bireysel olarak kırk dokuz öğrenci ile gerçekleştirilen mülakat sonucunda belirlenen kavram yanılgıları, tanı testinde elde edilen kavram yanılgıları ile benzerlik göstermiştir. Tespit edilen kavram yanılgılarının bir bölümü literatürdeki çalışmalarla paralellik göstermesine rağmen, bu çalışma sonucunda daha önce ünite ile ilgili olarak ortaya konulmayan kavram yanılgıları da tespit edilmiştir. Eğitimcilerin, ders tasarımları geliştirirken bu kavram yanılgılarını dikkate alması, "Canlıları Tanıyalım” ve "İnsan ve Çevre İlişkileri” konularını öğrenecek öğrencilerin zihinlerinde bu kavramları daha doğru şekilde yapılandırmalarına katkı sağlayacaktır.

Anahtar Kelimeler: canlılar dünyası, çevre sorunları, kavram yanılgısı, üç aşamalı test

\section{Misconceptions of Fifth Grade Students about the "Let's Travel and Learn about the}

\section{Living World" Unit}

\footnotetext{
*Uluslararası Fen; Matematik, Girişimcilik ve Teknoloji Kongresinde sunulan sözlü bildirimin genişletilmiş versiyonu olan çalışma Ondokuz Mayıs Üniversitesi Bilimsel Araştırma Projeleri kapsamında PYO.EGF.1904.14.006 no'lu proje olarak desteklenen birinci yazarın doktora tezinin bir parçasından oluşmaktadır.

${ }^{* *}$ Dr. /Fen Bilimleri Öğrt.,MEB, Tevfik İleri İHO, Atakum, Samsun, evsenaymen@ hotmail.com ORCID ID: 0000-00030969-5753

***Doç. Dr. Ordu Üniversitesi, Eğitim Fakültesi, Matematik ve Fen Bilimleri Eğitimi Bölümü, Fen Bilgisi Eğitimi Bilim Dalı, Cumhuriyet Kampüsü, Ordu, eroltas@odu.edu.tr ORCID ID: 0000-0003-4077-7351
} 
Abstract: The study was carried out in order to determine the misconceptions of the 5th grade students about the "Let's Travel and Learn about the Living World" unit in the 2014-2015 academic year. 226 fifth grade students from three different schools participated in this study. In the study that quantitative and qualitative research methods were applied, qualitative data were obtained from semi-structured interviews and quantitative data were obtained from threetier concept diagnosis test. The data obtained from the concept diagnostic test were evaluated with the application prepared in Microsoft Excel. Thus, students 'misconceptions and students' missing information were determined. As a result of the study, a total of forty misconceptions which were related to twelve of the twenty-three questions found in the diagnostic test were identified. The misconceptions determined as a result of the interviews attended by 26 students showed similarities with the misconceptions obtained in the diagnostic test. Although some of the misconceptions detected are in parallel with the studies in the literature, misconceptions about the unit which were not revealed before were determined in this study. If the educators take into account the misconceptions determined while developing the course designs, the students who will learn "Let's of Living Things" and "Human-Environment Relationship" will be able to construct these concepts in their minds more accurately.

Keywords:living world, environmental problems, misconceptions, three-tier test

\section{Giriş}

Kavram, bir nesne veya düşüncenin zihindeki soyut ve genel tasarımı olarak tanımlanabileceği gibi (Türk Dil Kurumu (TDK), 2018), nesne, eylem, olay, fikir ve düşünceleri benzerliklerine göre gruplandırdığımızda oluşan gruplara verilen addır (Malatyalı ve Y1lmaz, 2010). Bir başka ifadeyle kavram, nesne ve düşüncelerin insan zihninde canlandırıldığı, soyut bir düşünce birimidir (Ülgen, 2001; Yağbasan ve Gülçiçek, 2003). Kavramlar içinde bulunulan çevrenin karmaşıklığını azaltıp, çevre ve dünyadaki nesne ve olayların tanınmasına yardımcı olan soyut düşüncelerdir (Osborne ve Freyberg, 1985, aktaran Bacanak, Küçük ve Çepni, 2004).

İnsanlar, çocukluktan başlayarak kavram ve onlarla ilişkili sözcükleri öğrenmeye başlamakta, sınıflandırmakta ve kavramlar arasındaki ilişkileri, bir başka ifadeyle yeni bilgileri fark etmektedir. Bilişsel yapıda yer alan kavramlara yenilerinin eklenmesi, düzenlenmesi ya da yeniden yapılandırılması yaşam boyu sürmektedir (Kaptan, 1999). Dolayısıyla, okul yaşantıları başlayan çocuklar, yaşam tecrübelerine dayalı olarak oluşturdukları bilgi ve kavramları sınıf ortamlarına getirmektedir. Yapılan araştırmalar, okul dışında oluşturulmuş bu ön bilgi ve 
kavramların öğrenme üzerinde büyük bir etkisinin olduğunu ortaya koymaktadır (Ausubel, 1968; Novak, 1998; Richardson, 2003).

Öğrencilerin günlük yaşam ve deneyimleri, inançları, öğrenme ortamları, gelişmemiş zihinsel becerileriyle kavramları anlamlandırma çabaları gibi etkenler bilimin doğası ve bilimsel bilgiler ile çelişmekte ve öğrenciler bu süreçte bilimsel bilgiye yanlış anlamlar yüklemektedir. $\mathrm{Bu}$ şekildeki bilimsel olmayan anlamlandırma süreci, kavram yanılgısı (misconception) veya alternatif kavrama (alternative conception) terimleriyle açıklanmaktadır (Ercan, Taşdere ve Ercan, 2010). Kavram yanılgılarını belirlemede, kavram haritaları (Altın ve Aslan, 2006; Çıldır ve Şen, 2006; Roth ve Roychoughury, 1992), kavram karikatürleri (Şaşmaz Ören, Karatekin, Erdem ve Ormanc1, 2012), Tahmin-Gözlem-Açıklama (TGA) (Köse, Coştu ve Keser, 2003), durum, olay ya da kavramlarla ilgili mülakatlar (Anıl ve Küçüközer, 2010; Buluş Kırıkkaya ve Güllü, 2008; Karakuyu ve Tüysüz, 2011), çizimler (Bolat, Aydoğdu, Uluçınar Sağır ve Değirmenci, 2014; Meşeci, Tekin ve Karamustafaoğlu, 2013), kelime ilişkilendirme (Ercan ve diğerleri, 2010), V diyagramları (Nakiboğlu ve Arık, 2006; Tortop, Çiçek Bezir, Uzunkavak ve Özek, 2007) ve kavram yanılgısı teşhis testleri kullanılabilmektedir.

Ülkemizde, okul öncesi dönemde basit deneylerle çocukların fen öğrenme süreci başlamaktadır. 3. sınıftan itibaren uygulanmaya başlanan Fen eğitiminin başlıca hedeflerinden birisi, öğrencilerin öğretim programında yer alan kavramları anlamlı ve kalıcı öğrenmelerini sağlamaktır (Köse ve Uşak, 2006). Öğrencilerin geçmiş yaşantılarına bağlı olarak, sınıf ortamına bazı kavramları öğrenmiş şekilde geldikleri düşünüldüğünde, fen konuları öğretilmeden önce, öğrencilerin konu ile ilgili sahip oldukları kavramların ortaya çıkarılması son derece önemlidir (Yağbasan ve Gülçiçek, 2003). Çünkü, öğrencilerin sahip oldukları kavram yanılgıları, sonraki öğrenmelerini negatif yönde etkileyecek, hatta bu kavram yanılgılarının ortaya çıkarılıp, doğru kavramlarla yer değiştirilmesi de oldukça zorlaşacaktır (Özdemir, 2012; Uyanık ve Dindar, 2016).

Fen Bilimleri dersi kazanımları hem somut hem de soyut kavramlar içermektedir (MEB; 2013, 2018). Bazı araştırmalar; özellikle soyut kavramların öğrenciler tarafından tam anlamıyla anlaşılamadığını ortaya koymaktadır (Bell, 1985; Marek, 1986; Osborne ve Cosgrove, 1983, aktaran Bacanak, Küçük ve Çepni, 2004). Öğrencilerin, Fen Bilimleri dersi öğretim programında belirtilen dört farklı konu alanıyla ilişkili kavram yanılgılarına sahip olduğunu gösteren çalışmalara rastlanmaktadır (Derman, 2019). Örneğin, Allen (2010), Arsal (2010), Başoğlu (2017), Baysarı (2007), Braund (2010), Caner (2008), Çardak (2002), Çetinkaya (2010), Çinici (2011), Dikmenli, Türkmen ve Çardak (2002), Mutlu ve Tokcan (2012), 
Özyılmaz Akamca (2008), Saka, Ayas ve Enginar (2002), Summers, Kruger, Childs ve Mant (2000), Taş, Aymen Peker ve Çetinkaya (2014), Tekkaya, Çapa ve Yılmaz (2000), Türkmen, Çardak ve Dikmenli (2005), Ürey, Şahin ve Şahin (2011) ile Yen, Yao ve Mintzes (2007) gibi araştırmacılar canlıların sınıflandırılması / çevre sorunları kavramları ile ilgili yürüttükleri çalışmalarda öğrencilerin kavram yanılgılarına sahip olduğunu tespit etmiştir. $\mathrm{Bu}$ araştırmacıların araştırmalarında öğretmen adayları ya da öğretmenler; ilkokul, ortaokul veya lise öğrencileriyle çalıştıkları ve genellikle de canlıların sınıflandırılması konusu ile ilgili kavram yanılgılarını belirledikleri dikkat çekmektedir. 5. sınıf öğrencileri ile yürütülen çalışmaların 2013 öğretim programı öncesinde gerçekleştirildiği ve yalnızca canlıların sınıflandırılması konusuna odaklanıldığı görülmektedir. Ayrıca fen eğitimi alanında kavram yanılgıları konusunda yazılan makalelerin içerik analizini yapan Aydoğan ve Köksal (2017), Canlılar Dünyası ünitesi için 4. ve 5. sınıf öğrencileri ile yapılan çalışmaların az sayıda olduğunu belirtmektedir.

Bu çalışmanın amacı ortaokul 5. sınıf öğrencilerinin "Canlılar Dünyasını Gezelim ve Tanıyalım” ünitesi ile ilgili kavram yanılgılarını tespit etmek ve alanda çalışan bilim insanları ve eğitimciler için bu konu ile ilgili kaynak oluşturmaktır.

\section{Yöntem}

Bu çalışmada, öğrencilerin Canlılar Dünyasını Gezelim ve Tanıyalım ünitesi ile ilgili sahip oldukları kavram yanılgılarının tespit edilme sürecinde, nicel ve nitel verilerin bir arada değerlendirildiği karma araştırma yöntemi kullanılmıştır. Çalışmada; nitel veriler yarı yapılandırılmış görüşmelerden, nicel veriler ise üç aşamalı kavram tanı testinden elde edilmiştir.

Karma yöntem araştırmaları, araştırmacıların tek bir çalışmada veya birbirini takip eden çalışmalar içerisinde, nicel ve nitel yöntemleri bir arada kullanarak gerçekleştirdiği araştırmalardır (Creswell, 2003; Tashakkori ve Teddlie, 1998). Karma yöntem araştırması ile tek başına nitel veya nicel araştırma ile cevaplanamayacak olan araştırma sorularının yanıtlarına ulaşılabilmektedir (Creswell ve Plano Clark, 2015). Bu çalışmada da nicel verilerle elde edilen bulgular, nitel verilerden elde edilen bulgularla birlikte değerlendirilerek, araştırma sorusu ile ilgili daha net ve doğru sonuca ulaşılması hedeflenmiştir.

\section{Katılımcilar}


2014-2015 eğitim öğretim yılında Samsun'da yürütülen çalışmanın katılımcıları aynı ilçede bulunan üç farklı okuldan 226 ortaokul beşinci sınıf öğrencisidir. Araştırmaya katılan öğrencilerle ilgili bilgiler Şekil 1'de yer almaktadır.

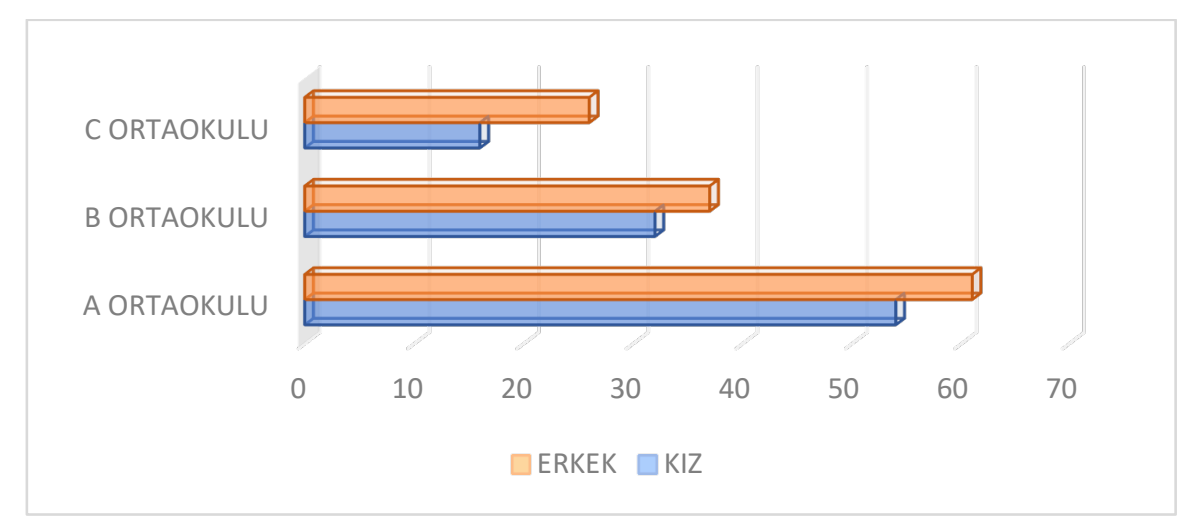

Şekil1.Katılımcılara Ait Bilgiler.

\section{Veri Toplama Araçları}

Öğrencilerin ünite ile ilgili sahip olduğu kavram yanılgılarını belirleyebilmek için nicel ve nitel veri kaynaklarına başvurulmuştur. Nicel veriler Aymen Peker ve Taş (2019)'ın geliştirdiği 23 maddelik üç aşamalı kavram tanı testi ile, nitel veriler ise yarı yapılandırılmış görüşmeler ile elde edilmiştir.

Üç aşamalı kavram tanı testi, öğrenciler "Canlılar Dünyasını Gezelim ve Tanıyalım” ünitesi ile ilgili herhangi bir öğrenme deneyimi yaşamadan önce öğrencilere uygulanmış, böylece 5. sınıf öğrencilerinin ünite ile ilgili ne tür kavram yanılgılarına sahip şekilde beşinci sınıfa geldikleri tespit edilmeye çalışılmıştır. Yarı yapılandırılmış görüşmeler ise öğrenciler ünite ile ilgili öğrenme deneyimi yaşadıktan sonra gerçekleştirilmiş, böylece öğrencilerde ünite konusunda ne tür kavram yanılgılarının devam ettiği belirlenmeye çalışılmıştır.

Araştırma sürecinde kullanılan kavram tanı testinin KR-20 güvenirlik katsayısı .80, üç madde birlikte değerlendirildiğinde testin ortalama güçlük ve ayırt edicilik değerleri sırasıyla pj: .47 ve rjx: .52'dir. Bu değerler araştırmada kullanılan testin güvenilir, orta güçlükte ve çok iyi maddelerden oluştuğunu göstermektedir (Aymen Peker ve Taş, 2019). Üç aşamalı kavram tanı testindeki soru maddelerinin konu ve kazanım dağılımı Tablo 1'de yer almaktadır.

Tablo 1.

$\ddot{U}$ Ç Aşamalı Kavram Tanı Testi Soru Maddelerinin Konu ve Kazanım Dağılımı 


\begin{tabular}{llll}
\hline Konular & Kazanımlar & $\begin{array}{l}\text { Madde } \\
\text { Numarası }\end{array}$ & $\begin{array}{l}\text { Madde } \\
\text { Sayısı }\end{array}$ \\
\hline Canlıları & 5.5.1.1. Canlılara örnekler vererek benzerlik ve & $1,2,3,4,5,6,7,9,16$, & 11 \\
Tanıyalım & farklılıklarına göre gruplandırır. & 21,23 & \\
İnsan ve Çevre & 5.5.2.1. Insan faaliyetleri sonucunda oluşan çevre & $8,10,11,12,13,15$, & 11 \\
İlişkisi & $\begin{array}{l}\text { sorunlarını araştırır ve bu sorunların çözümüne } \\
\text { ilişkin önerilerde bulunur. }\end{array}$ & $17,18,19,21,22$ & \\
& 5.5.2.2. Yakın çevresindeki bir çevre sorununun & 14 & \multirow{2}{*}{1} \\
& çözümüne ilişkin proje tasarlar ve sunar. & & \\
\hline
\end{tabular}

Üç aşamalı testte birinci aşama soruları, ünitede yer alan üç kazanıma yönelik çoktan seçmeli sorulardır. İkinci aşama soruları öğrencilerin birinci aşama sorusuna verdikleri cevabın nedenini keşfetmeye yöneliktir. Bu sorular literatür taraması yapılarak daha önce tespit edilen ilgili üniteye ait kavram yanılgılarını da içermektedir. Üçüncü aşama soruları ise öğrencinin soruya verdiği yanıttan ne derece emin olduğunu sorgulamaya yöneliktir. Şekil 2'de çalışmada kullanılan kavram tanı testinde yer alan bir soru örnek olarak yer almaktadır.
Soru 9.1.
I-İskelete sahip olma
II- Dışarıdan beslenme
III-Solunum Yapma
IV-Doğurarak çoğalma
Yukarıdakilerden hangisi ya da hangileri tüm canlılar için ortak bir özelliktir?
A)Yalnız IV
B) Yalnı III
C) II ve III
D) I-II, ve III
Soru 9.2.
Bir önceki soruda seçtiğiniz cevabın nedeni aşağıdakilerden hangisidir?
A. Tüm canlılar solunum yapar ve dışarıdan beslenir.
B. Tüm canlılar solunum yapar, bir iskelete sahiptir ve dışarıdan beslenir.
C. Bütün canlıların iskeleti vardır ve tüm canlılar dışarıdan beslenir.
D. Tek ortak özellik solunum yapma'dır.
E. Diğer.

Soru 9.3.

Bir önceki soruda verdiğiniz cevaptan ne kadar eminsiniz?
A) Eminim
B) Emin Değilim
C) Tahmin Ettim

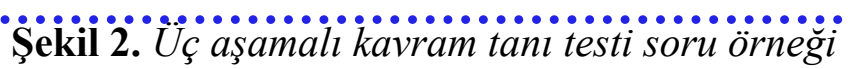

Araştırmanın nitel veri kaynağını oluşturan mülakat sürecinde öğrencilere ilk olarak “Uygulama öncesinde ...şeklinde biliyordum, ancak uygulama sonrasında doğrusunun ....... olduğunu fark ettim. dediğin neler var? sorusu yöneltilmiştir. İkinci olarak "Birazdan sana bazı canlı isimleri okuyacă̆ım. Bu canlıların hangi canlılar grubuna dâhil olduğunu nedeniyle belirtmeni isteyeceğim" şeklinde bir açıklama yapılmıştır. Görüşmeler gerçekleştirilirken ses kaydı alınmış daha sonra görüşmelerin çözümlemesi iki araştırmacı tarafından ayrı ayrı yapılmıştır. 
Üç aşamalı kavram tanı testi uygulamasıyla katılımcılarla tanışan ilk araştırmacı, ünitede öğrenme sürecinde mümkün olduğunca sınıf ortamında bulunmuştur. Böylece görüşme gerçekleştirdiği öğrencilerle uzun süreli etkileşimde bulunarak, çalışmanın iç geçerlik düzeyinin (inandırıcılığın) artması sağlanmıştır. Yine mülakat sürecinde katılımcıdan alınan yanıt konusunda özetleme yapılarak, katılımcının söylediği şeyin doğru olup olmadığı teyit edilmeye çalışılmıştır. Bu sayede de araştırmanın inandırıcılığının artması sağlanmıştır. Ayrıca mülakat gerçekleştirilecek katılımcılar belirlenirken, kavram tanı testi başarı puanına göre yüksek, orta ve düşük düzeyde puan alan öğrencilerden eşit sayılarda öğrenciler sürece dahil edilerek amaçlı örnekleme yapılmıştır. Veri kaynağının çeşitlendirilmesi yoluyla araştırmanın hem inandırıcılık hem de aktarılabilirlik (dış geçerlik) düzeyi artırılmıştır. Mülakat sürecinde mülakat gerçekleştirilen tüm katılımcılara öncelikle yukarıda belirtilen soruların sorulması ve görüşmelerin kayıt altına alınması ile de çalışmanın tutarlığı (iç güvenirlik) sağlanmıştır.

\section{Verilerin Analizi}

Üç aşamalı test analizinde, sorunun her bir aşamasına verilen yanıt dikkate alınmıştır. Peşman ve Eryılmaz (2010) ile Arslan, Çiğdemoğlu ve Moseley'in (2012) de çalışmalarında tanımladığı birinci aşama, her iki aşama, toplam, emin olma, bilgi eksikliği, birinci aşama, her iki aşama ve tüm aşama kavram yanılgısı puanları olmak üzere sekiz ayrı puan MS Excel programında geliştirilen makro uygulamadan yararlanılarak elde edilmiştir. $\mathrm{Bu}$ işlem sonrasında, kavram yanılgısı, bilimsel bilgi, şanslı cevap ve bilgi eksikliği olmak üzere dört kategori şeklinde bulgulara ulaşılmıştır (Tablo 2). Elde edilen veriler Arslan ve diğerlerinin (2012) çalışmasında önerdiği, Taş ve diğerlerinin (2014) araştırmasında kullandığı Tablo 2'de yer alan değerlendirme tablosu ile değerlendirilmiştir.

Tablo 2.

Üç aşamalı testte mümkün olan olası yanıtlar ve bunların kategorileri

\begin{tabular}{llll}
\hline \multirow{2}{*}{ Kategoriler } & $\begin{array}{l}\text { Birinci Aşama } \\
\text { Sorusu }\end{array}$ & $\begin{array}{l}\text { İkinci Aşama } \\
\text { Sorusu }\end{array}$ & $\begin{array}{l}\text { Üçüncü Aşama } \\
\text { Sorusu }\end{array}$ \\
\hline Bilimsel Bilgiye Sahip & Doğru & Doğru & Emin \\
Bilgi Eksikliği & Doğru & Yanlış & Emin değil \\
Bilgi Eksikliği & Yanlış & Doğru & Emin değil \\
Bilgi Eksikliği & Yanlış & Yanlış & Emin değil \\
Tahmini Şanslı cevap & Doğru & Doğru & Emin değil \\
Kavram Yanılgısı (Pozitif yönde Yanlış) & Doğru & Yanlış & Emin \\
Kavram Yanılgısı (Negatif yönde Yanlış) & Yanlış & Doğru & Emin \\
Kavram Yanılgısı & Yanlış & Yanlış & Emin \\
\hline
\end{tabular}

Arslan, Çiğdemoğlu ve Moseley (2012)'in çalışmasından alınmıştır. 
Çalışmanın nitel verilerini oluşturan ve öğrenme süreci tamamlandıktan sonra 49 öğrenci ile yapılan yarı yapılandırılmış görüşmelerden elde edilen veriler betimsel olarak analiz edilmiştir. Katılımcıların yanıtlarına herhangi bir müdahale yapılmadan yanıtlar MS Excel programında katılımcı kodu ile kaydedilmiştir. Yanıtların tamamı iki araştırmacı tarafından ayrı ayrı incelenerek, kavram yanılgısı olan ve olmayan ifadeler şeklinde gruplandırılmıştır. Araştırmacılar elde ettikleri sonuçları karşılaştırarak kavram yanılgısı olan katılımcılar belirlenmiştir. Veriler değerlendirildiğinde, yirmi altı öğrencinin öğrenme süreci sonrasında kavram yanılgısına sahip olduğu gözlenmiştir. Analiz sürecinde veriler hayvan sınıflandırması ve bitki sınıflandırması ile ilgili kavram yanılgıları şeklinde iki ayrı tema altında sınıflandırılmıştır. Bu sınıflandırma sürecinde katılımcı yanıtları alıntı şeklinde yazılmıştır. Araştırma sonucunda tespit edilen kavram yanılgılarının daha önce belirlenen kavram yanılgıları ile benzerlik durumları karşılaştırılmak suretiyle yorumlanmıştır.

\section{Bulgular}

Microsoft Excel programında hazırlanan uygulama ile öğrencilerin verileri değerlendirilip başarı yüzdeleri hesaplandığında Tablo 3 'deki verilere ulaşılmıştır.

Tablo 3.

Ögrencilerin Ön Test Cevap Yüzdeleri

\begin{tabular}{|c|c|c|c|c|c|c|c|}
\hline \multirow{2}{*}{ Konu Alanı } & \multirow{2}{*}{$\begin{array}{r}\text { Madde } \\
\text { No }\end{array}$} & \multicolumn{3}{|c|}{ Doğru Cevap Oranı (\%) } & \multirow{2}{*}{$\begin{array}{r}\text { Bilgi } \\
\text { Eksikliği } \\
(\%) \\
\end{array}$} & \multirow{2}{*}{$\begin{array}{r}\text { Emin } \\
\text { Olma } \\
(\%)\end{array}$} & \multirow{2}{*}{$\begin{array}{r}\text { Kavram } \\
\text { Yanılgisı } \\
(\%) \\
\end{array}$} \\
\hline & & 1.aşama & 2.aşama & 3.aşama & & & \\
\hline \multirow{11}{*}{$\begin{array}{l}\text { Canlıları } \\
\text { Tanıyalım } \\
\text { (CT) }\end{array}$} & 1 & 66 & 57 & 31 & 31 & 43 & 12 \\
\hline & 2 & 81 & 72 & 49 & 18 & 59 & 10 \\
\hline & 3 & 55 & 51 & 36 & 36 & 49 & 12 \\
\hline & 4 & 50 & 34 & 19 & 50 & 35 & 16 \\
\hline & 5 & 77 & 33 & 24 & 32 & 59 & $\underline{35}$ \\
\hline & 6 & 70 & 67 & 55 & 15 & 73 & 18 \\
\hline & 7 & 87 & 47 & 32 & 31 & 54 & $\underline{22}$ \\
\hline & 9 & 56 & 47 & 36 & 26 & 64 & $\underline{27}$ \\
\hline & 16 & 45 & 40 & 31 & 31 & 60 & $\underline{29}$ \\
\hline & 21 & 23 & 16 & 4 & 66 & 22 & 18 \\
\hline & 23 & 48 & 17 & 11 & 26 & 67 & $\underline{56}$ \\
\hline
\end{tabular}




\begin{tabular}{|c|c|c|c|c|c|c|c|}
\hline \multirow{2}{*}{ Konu Alanı } & \multirow{2}{*}{$\begin{array}{r}\text { Madde } \\
\text { No }\end{array}$} & \multicolumn{3}{|c|}{ Doğru Cevap Oranı (\%) } & \multirow{2}{*}{$\begin{array}{r}\text { Bilgi } \\
\text { Eksikliğ } \\
(\%) \\
\end{array}$} & \multirow{2}{*}{$\begin{array}{r}\text { Emin } \\
\text { Olma } \\
(\%)\end{array}$} & \multirow{2}{*}{$\begin{array}{r}\text { Kavram } \\
\text { YanılgısI } \\
(\%) \\
\end{array}$} \\
\hline & & 1.aşama & 2.aşama & 3.aşama & & & \\
\hline $\begin{array}{l}\text { Ortalama } \\
\text { (CT) }\end{array}$ & & $\underline{59.82}$ & $\underline{43.73}$ & $\underline{29.82}$ & $\underline{32.91}$ & $\underline{\mathbf{5 3 . 1 8}}$ & $\underline{23.18}$ \\
\hline \multirow{12}{*}{$\begin{array}{l}\text { İnsan } \\
\text { Çevre } \\
\text { (İlişis }\end{array}$} & 8 & 70 & 65 & 52 & 24 & 63 & 11 \\
\hline & 10 & 72 & 50 & 45 & 12 & 83 & $\underline{38}$ \\
\hline & 11 & 46 & 43 & 21 & 41 & 37 & 17 \\
\hline & 12 & 87 & 76 & 70 & 13 & 81 & 11 \\
\hline & 13 & 57 & 50 & 36 & 31 & 55 & $\underline{20}$ \\
\hline & 14 & 63 & 50 & 32 & 31 & 51 & $\underline{20}$ \\
\hline & 15 & 61 & 54 & 47 & 28 & 65 & $\underline{20}$ \\
\hline & 17 & 60 & 50 & 29 & 34 & 45 & 16 \\
\hline & 18 & 60 & 53 & 39 & 29 & 56 & $\underline{20}$ \\
\hline & 19 & 70 & 63 & 33 & 27 & 43 & 10 \\
\hline & 20 & 31 & 16 & 10 & 50 & 45 & $\underline{35}$ \\
\hline & 22 & 59 & 52 & 39 & 28 & 59 & $\underline{20}$ \\
\hline $\begin{array}{l}\text { Ortalama } \\
\text { (İÇí) }\end{array}$ & & $\underline{61.33}$ & $\underline{51.83}$ & $\underline{\mathbf{3 7 . 7 5}}$ & $\underline{29.00}$ & $\underline{56.92}$ & $\underline{19.83}$ \\
\hline
\end{tabular}

Tablo 3 incelendiğinde, öğrencilerin soru maddelerini doğru cevaplandırma oranlarının sorunun sadece 1. aşama sorusu dikkate alındığında, daha yüksek olduğu görülmektedir. Konu alanı açısından karşılaştırma yapıldığında; İnsan ve Çevre İlişkisi konusu sorularını doğru cevaplandırma yüzdeleri (1.aşama: 61.33, 2. aşama: 51.83 ve 3. aşama: 37.75), Canlıları Tanıyalım alanı (1.aşama: 59.82, 2.aşama: 43.73 ve 3.aşama: 29.82) sorularına göre daha fazladır. Öğrencilerin kavram yanılgısı oranları incelendiğinde kavram yanılgısı oranı \%20 üzerinde olan sorular öğrencilerin kavram yanılgısına sahip olduğu sorular olarak belirlenmiştir. Canlıları Tanıyalım konusu ile ilgili olan 5., 7., 9., 16. ve 23. sorular ile İnsan ve Çevre konusu ile ilgili 10., 13., 14., 15., 18, 20. ve 22. sorularda kavram yanılg1sı oranı \%20'nin üzerindedir ve bu sorular aracılığıyla öğrencilerin kavram yanılgıları tespit edilmiştir.

Veri değerlendirmesinin bu aşamasında, kavram yanılgısı oranı \%20 ve üzerinde olan on iki soru maddesi ayrıntılı olarak incelenmiştir. Öğrencilerin ilgili soruya yönelik ne tür bir kavram yanılgısına sahip olduğunu belirleyebilmek için belirlenen on iki soru maddesinin yanıt frekanslarını gösteren veri tabloları elde edilmiştir. Tablo verileri yorumlanırken, öğrencilerin test maddesinin üç aşamasına verdiği yanıtlar birlikte değerlendirilerek, soruya yönelik 
öğrencilerin kavram yanılgılarının neler olduğuna karar verilmiştir. Veri analizinde, 1. aşama ve 2. aşama soruları için, yanlış cevap olmasına rağmen \%10 üzerinde işaretlenen seçenekler belirlenerek, kavram yanılgıları tespit edilmiştir. Veriler tabloda gösterilirken, doğru cevap seçenekleri koyu renkle, yanlış cevap olmasına rağmen, \%10 üzerinde işaretlenen seçenekler ise koyu, italik ve altı çizili şekilde kutucuklar içerisinde gösterilmiştir.

Beşinci soru maddesinden başlamak üzere, kavram yanılgısı belirlenen on iki soru için elde edilen veri tabloları sırasıyla Tablo 4'den itibaren sunulmuştur.

Tablo 4.

Beşinci Soruya Verilen Yanıtların Frekans Değerleri

\begin{tabular}{rcrrrrrr}
\hline & Doğru Yanıt & A & B & C & D & E & Boș \\
\hline $\mathbf{5 - 1 .}$ & A & $\mathbf{. 7 7}$ & .03 & .12 & .06 & & .02 \\
$\mathbf{5 - 2 .}$ & A & $\mathbf{. 3 3}$ & $\underline{.37}$ & $\underline{.11}$ & .05 & $\underline{.11}$ & .03 \\
$\mathbf{5 - 3 .}$ & A & $\mathbf{. 5 9}$ & .15 & .24 & 0 & & .02 \\
\hline
\end{tabular}

Soru maddesinin 1.aşama sorusuna öğrencilerin \% 77 'sinin doğru yanıt verdiği gözlenen beşinci sorunun, 2. aşama sorusu için yanlış cevap olmasına rağmen \%10 ve üzerinde işaretlenen seçeneklerin $\mathbf{B}, \mathbf{C}$ ve $\mathbf{E}$ seçenekleri olduğu Tablo 4'de görülmektedir. Bu seçenekler dikkate alınarak belirlenen kavram yanılgıları şunlardır:

$\checkmark$ Hayvanlar yer değiştirerek hareket etmez.

$\checkmark$ Bazı hayvanlar kendi besinlerini üretmezler.

Tablo 5 .

Yedinci Soruya Verilen Yanttların Frekans Değerleri

\begin{tabular}{rrrrrrrr}
\hline & Doğru Yanıt & A & B & C & D & E & Boş \\
\hline 7-1. & C & .03 & .07 & $\mathbf{. 8 7}$ & .02 & & .01 \\
7-2. & $\mathrm{B}$ & .01 & $\mathbf{. 4 8}$ & $\underline{.11}$ & .04 & $\underline{.34}$ & .02 \\
7-3. & $\mathrm{A}$ & $\mathbf{. 5 4}$ & .25 & .20 & 0 & & .02 \\
\hline
\end{tabular}

Soru maddesinin 1.aşama sorusuna öğrencilerin \%87'sinin doğru yanıt verdiği gözlenen yedinci soru için, yanlış cevap olmasına rağmen, C ve E yanıtlarının \%10'un üzerinde işaretlendiği belirlenmiştir. Bu soruyla belirlenen kavram yanılgıları şu şekildedir.

$\checkmark$ Kuşlar yavrularını sütle besler.

$\checkmark$ Kuşlar doğurarak çoğalır.

Tablo 6. 
Dokuzuncu Soruya Verilen Yanıtların Frekans Değerleri

\begin{tabular}{rrrrrrrr}
\hline & Doğru Yanıt & A & B & C & D & E & Boș \\
\hline 9-1. & B & .02 & $\mathbf{. 5 6}$ & .04 & $\underline{.35}$ & & .02 \\
9-2. & $\mathrm{D}$ & .10 & $\underline{.26}$ & .07 & $\mathbf{. 5 0}$ & .04 & .03 \\
9-3. & $\mathrm{A}$ & $\mathbf{. 6 4}$ & .17 & .17 & 0 & & .02 \\
\hline
\end{tabular}

Dokuzuncu sorunun birinci aşama sorusunda D, ikinci aşama sorusunda ise B yanıtlarının yanlış cevap olmasına rağmen \% !0’un üzerinde işaretlendiği belirlenmiştir. $\mathrm{Bu}$ soruyla belirlenen kavram yanılgıları şu şekildedir.

$\checkmark$ Bir iskelete sahip olma tüm canlıların ortak özelliğidir.

$\checkmark$ Dışarıdan beslenme tüm canlıların ortak özelliğidir.

\section{Tablo 7.}

Onuncu Soruya Verilen Yanitların Frekans Değerleri

\begin{tabular}{rrrrrrrr}
\hline & Doğru Yanit & A & B & C & D & E & Boș \\
\hline $\mathbf{1 0 - 1 .}$ & $\mathrm{C}$ & .07 & .03 & $\mathbf{. 7 2}$ & $\underline{.18}$ & & .01 \\
$\mathbf{1 0 - 2}$ & $\mathrm{B}$ & $\underline{.15}$ & $\mathbf{. 5 5}$ & $\underline{. \mathbf{2 0}}$ & .04 & .05 & .01 \\
$\mathbf{1 0 - 3 .}$ & $\mathrm{A}$ & $\mathbf{. 8 3}$ & .05 & .11 & 0 & & .01 \\
\hline
\end{tabular}

Tablo 7 incelendiğinde ise birinci aşama sorusunda $\mathbf{D}$, ikinci aşama sorusunda ise $\mathbf{A}$ ve C yanıtlarının yanlış cevap olmasına rağmen \% 10'un üzerinde işaretlendiği belirlenmiştir. Bu soruyla belirlenen kavram yanılgıları şu şekildedir.

$\checkmark$ Çevreyi korumak için geri dönüşüm ürünleri kullanmamalıyız.

$\checkmark$ Çevreyi korumak için geri dönüşümlü ürünler kullanmamız yeterlidir.

Tablo 8.

On üçüncü Soruya Verilen Yanttların Frekans Değerleri

\begin{tabular}{rcrrrrrr}
\hline & Doğru Yanıt & $\mathbf{A}$ & $\mathbf{B}$ & $\mathbf{C}$ & $\mathbf{D}$ & $\mathbf{E}$ & Boș \\
\hline $\mathbf{1 3 - 1 .}$ & $\mathrm{B}$ & $\underline{\mathbf{. 1 4}}$ & $\mathbf{. 5 7}$ & $\underline{.11}$ & $\underline{.17}$ & & .01 \\
$\mathbf{1 3 - 2 .}$ & $\mathrm{A}$ & $\mathbf{. 5 7}$ & .08 & .08 & $\underline{.17}$ & .08 & .02 \\
$\mathbf{1 3 - 3 .}$ & $\mathrm{A}$ & $\mathbf{. 5 5}$ & .15 & .26 & 0 & & .04 \\
\hline
\end{tabular}


Tablo 8 incelendiğinde de öğrencilerin $\mathrm{A}, \mathrm{C}$ ve $\mathrm{D}$; ikinci aşama sorusunda da D yanıtlarının, yanlış cevap olmasına rağmen \%10’un üzerinde işaretlendiği belirlenmiştir. Bu soruyla belirlenen kavram yanılgıları şu şekildedir.

$\checkmark$ Bitki örtüsünün azalması sonucu toprak erozyonu oluşmaz.

$\checkmark$ Bitki örtüsünün azalması sonucu oradaki canlı sayısında azalma olmaz.

$\checkmark$ Bitki örtüsünün azalması sonucu bölge çoraklaşmaz.

$\checkmark$ Bölgenin çoraklaşması bitki örtüsünün azalmasının nedenidir.

Tablo 9.

On dördüncü Soruya Verilen Yanttların Frekans Değerleri

\begin{tabular}{rcrrrrrr}
\hline & Doğru Yanıt & A & B & C & D & E & Boş \\
\hline $\mathbf{1 4 - 1 .}$ & $\mathrm{B}$ & $\underline{\mathbf{. 1 6}}$ & $\mathbf{. 6 3}$ & .08 & .08 & & .05 \\
$\mathbf{1 4 - 2 .}$ & $\mathrm{C}$ & $\underline{\mathbf{. 1 2}}$ & .10 & $\mathbf{. 5 8}$ & .09 & .04 & .07 \\
$\mathbf{1 4 - 3 .}$ & $\mathrm{A}$ & $\mathbf{. 5 1}$ & .18 & .26 & 0 & & .05 \\
\hline
\end{tabular}

Öğrencilerin birinci ve ikinci aşama sorusunda yanlış cevap olmasına rağmen, A yanıtını \%10'un üzerinde oranda işaretlediği belirlenmiştir. Bu soruyla belirlenen kavram yanılgıları şu şekildedir.

$\checkmark$ Tarımda kimyasal ilaç ve gübre kullanımını azaltma konusunda çalışma yapmak çevre sorunlarını azaltmayacaktır.

Tablo 10.

On beşinci Soruya Verilen Yanıtların Frekans Değerleri

\begin{tabular}{rcrrrrrr}
\hline & Doğru Yanıt & A & B & C & D & E & Boş \\
\hline $\mathbf{1 5 - 1 .}$ & B & $\underline{.15}$ & $\mathbf{. 6 1}$ & $\underline{.13}$ & .07 & & .04 \\
$\mathbf{1 5 - 2 .}$ & $\mathrm{B}$ & $\underline{. \mathbf{1 2}}$ & $\mathbf{. 5 8}$ & $\underline{.11}$ & .08 & .07 & .05 \\
$\mathbf{1 5 - 3 .}$ & $\mathrm{A}$ & $\mathbf{. 6 5}$ & .15 & .15 & .01 & & .05 \\
\hline
\end{tabular}

Tablo 10 incelendiğinde de öğrencilerin her iki aşamada da yanlış seçenekler olan A ve C yanıtlarını \%10'un üzerinde oranda işaretlediği belirlenmiştir. Bu soruyla belirlenen kavram yanılgıları şu şekildedir.

$\checkmark$ Su kirliliğinin artması Karadeniz'de yaşayan bir balık türüne ait birey sayısının zamanla azalmasında etkili değildir.

$\checkmark$ Karadeniz'de yaşayan bir balık türüne ait birey sayısının zamanla azalması ile avlanma oranının artması arasında bir ilişki yoktur.

$\checkmark$ Balıkların beslenme olanaklarının azalması balık sayısının azalmasına neden olmaz. 
Tablo 11.

On altıncı Soruya Verilen Yanttların Frekans Dĕgerleri

\begin{tabular}{rcrrrrrr}
\hline & Doğru Yanıt & A & B & C & D & E & Boş \\
\hline $\mathbf{1 6 - 1 .}$ & $\mathrm{B}$ & $\underline{. \mathbf{3 2}}$ & $\mathbf{. 4 5}$ & .07 & .09 & & .06 \\
$\mathbf{1 6 - 2 .}$ & $\mathrm{C}$ & $\underline{. \mathbf{2 8}}$ & 0 & $\mathbf{. 5 1}$ & .08 & .07 & .06 \\
$\mathbf{1 6 - 3 .}$ & $\mathrm{A}$ & $\mathbf{. 6 0}$ & .11 & .23 & 0 & & .06 \\
\hline
\end{tabular}

On altıncı soru için öğrencilerin 1.ve 2.aşama sorusunda yanlış seçeneği \%10 üzerinde oranda işaretlediği belirlenmiştir. Bu soruyla belirlenen kavram yanılgısı ise şu şekildedir.

$\checkmark$ Yarasa bir kuştur.

Tablo 12.

On sekizinci Soruya Verilen Yanıtların Frekans Dĕgerleri

\begin{tabular}{|c|c|c|c|c|c|c|c|}
\hline & Doğru Yanıt & $\mathbf{A}$ & B & C & D & $\mathbf{E}$ & Boș \\
\hline $18-1$. & $\mathrm{C}$ & .04 & .27 & .60 & .04 & & .04 \\
\hline $18-2$. & $\mathrm{A}$ & .56 & .45 & .09 & .05 & .06 & .05 \\
\hline 18-3. & $\mathrm{A}$ & .56 & .16 & .24 & 0 & & .03 \\
\hline
\end{tabular}

Tablo 12 incelendiğinde de öğrencilerin her iki aşama sorusunda da yanlış seçenek olan B yanıtını \%10'un üzerinde oranda işaretlediği belirlenmiştir. Bu soruyla belirlenen kavram yanılgısı şu şekildedir.

$\checkmark$ Endüstriyel atıklar, toprak kirliliğine neden olurken, su kirliliğine neden olmaz.

Tablo 13.

Yirminci Soruya Verilen Yanitların Frekans Değerleri

\begin{tabular}{|c|c|c|c|c|c|c|c|}
\hline & Doğru Yanıt & $\mathbf{A}$ & B & $\mathrm{C}$ & D & $\mathbf{E}$ & Boș \\
\hline $20-1$. & $\mathrm{D}$ & .08 & .19 & .39 & .31 & & .02 \\
\hline $20-2$. & B & .34 & .33 & .04 & .14 & .12 & .03 \\
\hline 20-3. & A & .45 & .23 & .31 & 0 & & .02 \\
\hline
\end{tabular}

Tablo 13 incelendiğinde de öğrencilerin birinci aşama sorusunda $\mathbf{B}$ ve $\mathbf{C}$, ikinci aşama sorusunda ise $\mathbf{A}, \mathbf{D}$ ve $\mathbf{E}$ yanıtlarını yanlış seçenek olmasına rağmen \%10'un üzerinde oranla işaretlediği belirlenmiştir. Belirlenen kavram yanılgıları şu şekildedir.

$\checkmark$ Yalıtım yaptırma, ısı ile alakalıdır. Hava kirliliği ile ilgili değildir.

$\checkmark$ Evlere yalıtım yapılması ile hava kirliliğinin alakası yoktur.

$\checkmark$ Kaliteli yakıt kullanımı ile hava kirliliği arasında bir bağlantı yoktur.

Tablo 14. 
Yirmi ikinci Soruya Verilen Yanıtların Frekans Değerleri

\begin{tabular}{rccccccr}
\hline & Doğru Yanıt & A & B & C & D & E & Boş \\
\hline $\mathbf{2 2 - 1 .}$ & C & $\underline{.13}$ & $\underline{.12}$ & $\mathbf{. 5 9}$ & $\underline{.13}$ & & .03 \\
$\mathbf{2 2 - 2 .}$ & $\mathrm{B}$ & $\underline{\mathbf{. 1 2}}$ & $\mathbf{. 5 9}$ & $\underline{.14}$ & $\underline{.11}$ & .030 & .02 \\
$\mathbf{2 2 - 3 .}$ & $\mathrm{A}$ & $\mathbf{. 5 9}$ & .21 & .19 & 0 & & .02 \\
\hline
\end{tabular}

Tablo 14 incelendiğinde de öğrencilerin birinci aşama sorusunda $\mathbf{A}, \mathbf{B}$ ve $\mathbf{D}$, ikinci aşama sorusunda ise A, C ve D yanıtlarını yanlış seçenek olmasına rağmen \%10'un üzerinde oranla işaretlediği belirlenmiştir. Belirlenen kavram yanılgıları şu şekildedir.

$\checkmark$ Sanayi kuruluşları, su kirliliği nedenleri arasında bulunmaz.

$\checkmark$ Enerji üretim santrallerinin su kirliliğinde etkisi yoktur.

$\checkmark$ Asit yağmurları su kirliliğine yol açmaz.

$\checkmark$ Sanayi kuruluşları çevreci işlemler yaparlar.

$\checkmark$ Enerji üretim santralleri çevremizi korur.

$\checkmark$ Asit yağmurları su kirliliği sonucu oluşur.

Tablo 15.

Yirmi üçüncü Soruya Verilen Yanıtların Frekans Değerleri

\begin{tabular}{rrrrrrrr}
\hline & Doğru Yanıt & A & B & C & D & E & Boş \\
\hline $\mathbf{2 3 - 1 .}$ & $\mathrm{B}$ & .02 & $\mathbf{. 4 8}$ & $\underline{.45}$ & .03 & & .01 \\
$\mathbf{2 3 - 2 .}$ & $\mathrm{B}$ & $\underline{. \mathbf{3 9}}$ & $\mathbf{. 1 8}$ & $\underline{. \mathbf{3 1}}$ & .08 & .03 & .02 \\
$\mathbf{2 3 - 3}$ & $\mathrm{A}$ & $\mathbf{. 6 7}$ & .13 & .18 & 0 & & .01 \\
\hline
\end{tabular}

Tablo 15 incelendiğinde de öğrencilerin yanlış seçenekler olmalarına rağmen, birinci aşama sorusunda $\mathbf{C}$, ikinci aşama sorusunda ise $\mathbf{A}$ ve $\mathbf{C}$ yanıtlarını \%10'un üzerinde oranla işaretlediği belirlenmiştir. Bu soruyla belirlenen kavram yanılgıları şu şekildedir.

$\checkmark$ Yılan omurgalı bir hayvan değildir.

$\checkmark$ Yılan omurgalı hayvan değil, sürüngendir.

$\checkmark$ Kelebeğin vücudu çok küçüktür, içinde kemik yoktur.

$\checkmark$ Kelebeğin içinde kemik olmadığı için omurgalı hayvan değildir.

Öğrenme süreci tamamlandıktan sonra öğrenciler ile gerçekleştirilen yarı yapılandırılmış görüşmelerde öğrencilerin verdiği yanıtlar betimsel olarak incelendiğinde, yirmi altı öğrencinin öğrenme süreci sonrasında kavram yanılgısına sahip olduğu gözlenmiştir. Elde edilen veriler bitki ve hayvan sınıflandırılması başlıklarında sıralanmıştır.

$\underline{\text { Hayvan Sinıflandırılması Konusunda Belirlenen Kavram Yanılgıları }}$ 
AF02: Köpekbalı̆̆ı omurgalıdır. Memeliler grubunda yer almaktadır.

AF04: Yarasa omurgasiz canlıdır.

AF05: Kurbă̆a omurgası, kelebek omurgalı canlıdır.

AF13: Kelebek omurgasızdır. Kuşlar grubunda yer alır.

AF16: Kelebek ve yarasa kuştur.

AF17: Kurbağa omurgall-sürüngen grubunda yer almaktadır. Ayrıca balina bir tür balıktır.

GH04: Köpekbalı̆̆ı memeli canlıdır.

GH30: Yılan sürüngendir ve omurgasız canlılar grubundadır.

SA10: Yılanın omurgasız olduğunu düşünüyorum.

SA11: Yllan ve fok omurgasızdir.

SB11: Yılan omurgasız canlıdır. Balina ve fok balıktır.

SB16: Yllan omurgasızdir.

SB15: Yılan ve fok omurgasız, yarasa kuştur.

SC09: Balina ve fok balık, yarasa kuştur,

SC10: Yllan ve yarasa omurgasızdir.

SD05: Yarasa bir kuştur.

$\underline{\text { Bitki Sınıflandırılması Konusunda Belirlenen Kavram Yanılgıları }}$

AF05:Eğrelti otu çiçekli, kavak çiçeksiz bitkidir.

AF10: Kavak, çiçeksiz bitkidir.

SA11: Ĕgrelti otu çiçekli bitkidir.

SB11:Kavak çiçeksiz bitkidir.

SB12: Limon çiçeksiz bitkidir.

SB14: Kavak ăgacı çiçeksiz bitkidir.

SB15: Kavak ağacı çiçeksiz bitkilere örnektir.

SC09: Kavak çiçeksiz bitki grubuna girmektedir.

SC10: Kavak, çiçeksiz bitkidir.

SD05: Kavak çiçeksiz bitkidir.

Mülakatlarda belirtilen öğrenci görüşleri incelendiğinde, üç aşamalı başarı testinde belirlenen bazı kavram yanılgılarının örneğin Yarasa bir kuştur (Tablo 11), Yllan omurgalı bir hayvan değildir, Kelebeğin içinde kemik olmadı̆̆ı için omurgalı hayvan değildir (Tablo 15) gibi kavram yanılgılarının ifade edildikleri gözlenmektedir. Bunların dışında öğrencilerin Balina bir balıktır.; Yunus bir balıktır.; Kaplumbă̆a omurgasız bir canlıdır.; Kavak ăgacı çiçeksiz bir bitkidir.; Ăgaçlar cansız varlıklardır.; Mürekkep balığı omurgasız canlıdır.; 
Karınca mikroskobik canlıdır.; Amip, bitkiler grubuna dâhildir.; Mantarlar kendi besinlerini üretirler.; Mantarlar bitkilere dahildir.; Köpekbalı̆̆ memeli bir canlıdır.; Kelebek, kuşlar grubundadır.; Yarasa omurgasız canlıdır.; Kurbağa omurgasız bir canlıdır.; Solucan omurgalıdır.; Fok bir balıktır.; Fok, omurgasız bir canlıdır.; Böcekler omurgalıdır gibi kavram yanılgılarına sahip oldukları yapılan görüşmeler sonucunda belirlenmiştir.

\section{Tartışma ve Sonuç}

Kavram yanılgısı öğrencilerin bilim insanlarınca ortaya konan gerçeklerle çelişen, bilimsel olmayan anlamlandırma süreci olarak tanımlanmaktadır. Araştırma sonucunda öğrencilerin Canlıları Tanıyalım (20) ve İnsan- Çevre İlişskileri (20) konusu ile ilgili toplam kırk kavram yanılgısına sahip olduğu belirlenmiştir. Belirlenen kavram yanılgıları şunlardır:

\section{Canlıları Tanıvalım}

1.Bir iskelete sahip olma tüm canlıların ortak özelliğidir.

2.Dışarıdan beslenme tüm canlıların ortak özelliğidir.

3. Kuşlar yavrularını sütle besler.

4.Bazı hayvanlar kendi besinlerini üretmezler.

5. Kuşlar doğurarak çoğalır.

6. Hayvanlar yer değiştirerek hareket etmez.

7. Yarasa bir kuştur.

8. Yarasa omurgasız canlıdır.

9. Yılan omurgalı bir hayvan değildir.

10. Kelebek omurgalı canlıdır.

11.Yılan omurgalı hayvan değil, sürüngendir.

12.Kelebeğin vücudu çok küçüktür, içinde kemik yoktur.

13.Kelebeğin içinde kemik olmadığ için omurgalı hayvan değildir.

14.Köpekbalığı memeli bir canlıdır.

15.Kelebek omurgasızdır ve kuşlar grubunda yer alır.

16.Kurbağa omurgasız bir canlıdır.

17.Kurbağa omurgal1-sürüngen grubunda yer almaktadır.

18. Balina ve fok bir tür balıktır.

19. Kavak ve limon çiçeksiz bitkidir.

20.Eğrelti otu çiçekli bitkidir

\section{İnsan- Cevre İlișkileri}

1.Çevreyi korumak için geri dönüşüm ürünleri kullanmamalıyı.

2.Çevreyi korumak için geri dönüşümlü ürünler kullanmamız yeterlidir.

3.Bitki örtüsünün azalması sonucu toprak erozyonu oluşmaz.

4.Bitki örtüsünün azalması sonucu oradaki canlı sayısında azalma olmaz.

5.Bitki örtüsünün azalması sonucu bölge çoraklaşmaz.

6.Bölgenin çoraklaşması bitki örtüsünün azalmasının nedenidir.

7.Balıkların beslenme olanaklarının azalması balık sayısını azalmasina neden olmaz.

8.Yalıtım yaptırma, 1sı ile alakalıdır. Hava kirliliği ile ilgili değildir.

9. Kaliteli yakıt kullanımı ile hava kirliliği arasında bir bağlantı yoktur.

10. Endüstriyel atıklar, toprak kirliliğine neden olurken, su kirliliğine neden olmaz.

11.Tarımda kimyasal ilaç ve gübre kullanımını azaltma konusunda çalışma yapmak çevre sorunlarını azaltmayacaktır.

12.Su kirliliğinin artması Karadeniz'de yaşayan bir balık türüne ait birey sayısının zamanla azalmasında etkili değildir.

13.Karadeniz'de yaşayan bir balık türüne ait birey sayısının zamanla azalması ile avlanma oranının artması arasında bir ilişski yoktur.

14. Enerji üretim santrallerinin su kirliliğinde etkisi yoktur

15. Sanayi kuruluşları, su kirliliği nedeni değildir.

16. Asit yağmurları su kirliliğine yol açmaz.

17. Sanayi kuruluşları çevreci işlemler yaparlar.

18. Enerji üretim santralleri çevremizi korur.

19. Evlere yalıtım yapılması ve hava kirliliği alakalı değildir.

20.Asit yağmurları su kirliliği sonucu oluşur. 
Literatür incelendiğinde, bu araştırmada elde edilen kavram yanılgılarının belirlenmiş olduğu çalışmaların olduğu dikkat çekmektedir. Biyoloji öğretmen adaylarının kavram yanılgılarını inceleyen Tekkaya ve diğerleri (2000) ile lise öğrencilerinin kavram yanılgılarını araştıran Çinici (2011) ve Sivrikaya (2005) çalışmalarında, mevcut araştırmada belirlenen Yarasa bir kuştur kavram yanılgısını belirlemiştir. Yine bu çalışmada elde edilen sonuçla paralel şekilde dokuzuncu sınıf öğrencileri ile çalışan Çardak (2002) ve üniversite dördüncü sınıf öğrencileri ile çalışan Çetinkaya (2010) öğrencilerin, mevcut araştırmada ortaya çıkan Köpekbalığı memeliler grubundan bir canlıdır kavram yanılgısına sahip olduğunu ifade etmiştir. $\mathrm{Bu}$ araştırmada belirlenen kavram yanılgılarının hem ortaöğretim düzeyinde hem de öğretmen adaylarında tespit edilmiş olması, küçük yaşlardan itibaren var olan kavram yanılgılarının, gerekli tedbirler alınmadığında aynı şekilde bireylerde devam ettiğini ortaya koymaktadır. Demir ve Sezek (2009) de önlem alınmazsa, kavram yanılgılarının üst sınıflara taşınabileceğini, hatta öğretmen adaylarındaki yanılgılar giderilmediğinde bu kavram yanılgılarının onların öğrencilerine de aktarılabileceğini belirtmektedir.

İkinci, dördüncü ve altıncı sınıf öğrencilerinin hayvanlar alemi ve sınıflandırılması konusundaki alternatif görüşlerini belirleyen Dikmenli ve diğerleri (2002) öğrencilerin mevcut araştırmada da ortaya çıkan Kelebek ve yarasa kuş sınıfına dahildir kavram yanılgısına sahip olduklarını tespit etmiştir. Özdemir ve Çalışkan (2018) da beşinci ve altıncı sınıf öğrencileri ile yaptıkları çalışmada öğrencilerin kelebek ve yarasayı kuş sınıfına dahil ettikleri sonucuna ulaşmıştır. Benzer kavram yanılgısının ikinci sınıftaki öğrencilerde belirlenmiş olması, küçük yaştaki çocukların, okulda öğrenme süreci gerçekleşmeden, kanadı olan ve uçarak hareket eden canlıları zihinlerinde kuş kategorisine dahil etmeleri ile açıklanabilir. Nitekim Caner (2008) çalışmasında yarasa ve kelebeği kuş olarak sınıflandıran öğrencilerin gerekçe olarak "bu hayvanlar da kuşlar gibi uçuyor” şeklinde bir açıklama yaptıklarını belirtmektedir.

İlköğretimden yükseköğretime kadar farklı seviyelerde öğrencilerle çalışmalar gerçekleştiren Başoğlu (2017), Braund (2010), Caner (2008), Çinici (2011), Saka ve diğerleri (2002), Özdemir ve Çalışkan (2018), Ural Keleş (2009) ve Yen ve diğerleri (2007) gibi araştırmacılar, öğrencilerin Yılan omurgasızdır, Balina balıktır, Balina, fok, yunus yüzdüğü için balıktır gibi kavram yanılgılarına sahip olduğunu ortaya koymuştur. Mevcut araştırmada ise Yarasa, yılan ve kurbağa omurgasız canlıdır, balina ve fok bir tür balıktır şeklinde kavram yanılgıları belirlenmiştir. Omurgalı canlıların öğrenciler tarafından omurgasız canlı olarak sınıflandırılıyor olmaları Özdemir ve Çalışkan (2018)'ın da belirttiği gibi omurganın ne demek 
olduğunun öğrenciler tarafından tam olarak anlaşılamamasından kaynaklanabilir. Yine balina ve fok gibi memelilerin suda yaşıyor ve yüzüyor olmaları, bu canlıların öğrenciler tarafından balık olarak sınıflandırılma sebebi olarak açıklanabilir.

Çalışmada öğrencilerin, kurbağaların sınıflandırılması konusunda Kurbağa omurgallsürüngen grubunda yer almaktadır ve Kurbağa omurgasız bir canlıdır şeklinde iki farklı kavram yanılgısına sahip olduğu belirlenmiştir. Başoğlu (2017) ile Yen ve diğerleri (2007) öğrencilerin, bu çalışmada olduğu gibi Kurbă̆alar sürüngenler sınıfinda yer alır kavram yanılgısına sahip olduklarını tespit etmiştir. Öğrencilerin Kurbağaları sürüngen sınıfına dâhil etmeleri, sürüngenler sınıfında yer alan timsah ile kurbağalar arasında bir benzerlik kuruyor olmalarından kaynaklanabilir. Nitekim Tekkaya ve diğg. (2000) ile Yen ve dĭg. (2004) öğrencilerin, timsah ve kertenkele kurbağalar sınıfında yer alır şeklinde kavram yanılgılarının olduğunu ortaya koymuştur. $\mathrm{Bu}$ durum, öğrencilerin sürüngen ve iki yaşamlı canlıları karıştırdıklarını ortaya koymaktadır.

Baysarı (2007) öğrencilerin Memeliler kendi besinlerini üretir şeklinde kavram yanılgısına sahip olduklarını belirtirken mevcut çalışmada öğrencilerin Bazı hayvanlar kendi besinlerini üretmezler şeklinde bir kavram yanılgısına sahip olduğu tespit edilmiştir. Aslında memeliler, bitkiler gibi kendi besinlerini üreten canlılar değildir. Yavruların belirli bir olgunluğa ulaşıncaya kadar tükettikleri sütün, dişi memelilerin süt bezlerinde salgılanması, bazı öğrenciler açısından bazı hayvanların kendi besinlerini üretmeleri olarak algılanıyor olabilir.

Özyılmaz Akamca (2008) çalışmasında öğrencilerin, mevcut araştırmada da belirlenen Ĕgrelti otu çiçekli bitkidir kavram yanılgısına sahip olduğunu tespit etmiştir. Eğrelti otunun gövde yapısının çiçekli bitkilere benziyor olması öğrencilerin bu kavram yanılgısına sahip olma sebebi olarak açıklanabilir.

Ürey ve diğerleri (2011) çalışmasında öğretmen adaylarının asit yağmurları ile ilgili olarak Karbonmonoksit, kimyasal atıklar ve nükleer atıklar hem sera etkisine, hem ozon tabakasının incelmesine hem de asit yağmurlarına neden olur ve Asit yağmurları sonrasında seller meydana gelir şeklinde kavram yanılgısına sahip olduklarını ortaya koyarken mevcut araştırmada öğrencilerin konuyla ilgili olarak Asit yağmurları su kirliliğine yol açmaz ve Asit yağmurları su kirliliği sonucu oluşur şeklinde kavram yanılgılarına sahip oldukları sonucuna ulaşılmıştır. 
Araştırmada ayrıca, literatür taraması sonucunda belirlenmediği gözlenen Sanayi kuruluşları çevreci işlemler yaparlar, Enerji üretim santralleri çevremizi korur, Endüstriyel atıklar, toprak kirliliğine neden olurken, su kirliliğine neden olmaz, Yalıtım yaptırma, ısı ile alakalıdır. Hava kirliliği ile ilgili değildir, Evlere yalıtım yapılması ile hava kirliliğinin alakası yoktur, Kaliteli yakıt kullanımı ile hava kirliliği arasında bir bağlantı yoktur, Sanayi kuruluşları, su kirliliği nedenleri arasında bulunmaz, Enerji üretim santrallerinin su kirliliğinde etkisi yoktur, Çevreyi korumak için geri dönüşüm ürünleri kullanmamalıyı, Çevreyi korumak için geri dönüşümlü ürünler kullanmamı yeterlidir, Bitki örtüsünün azalması sonucu toprak erozyonu oluşmaz, Bitki örtüsünün azalması sonucu oradaki canlı sayısında azalma olmaz, Bitki örtüsünün azalması sonucu bölge çoraklaşmaz, Bölgenin çoraklaşması bitki örtüsünün azalmasının nedenidir, Tarımda kimyasal ilaç ve gübre kullanımını azaltma konusunda çalışma yapmak çevre sorunlarını azaltmayacaktır, Su kirliliğinin artması Karadeniz'de yaşayan bir balık türüne ait birey sayısının zamanla azalmasında etili değildir, Karadeniz'de yaşayan bir balık türüne ait birey sayısının zamanla azalması ile avlanma oranının artması arasında bir ilişki yoktur, Balıkların beslenme olanaklarının azalması balık sayısını azalmasına neden olmaz gibi İnsan-Çevre İlişkileri konusu ile ilgili ve Bir iskelete sahip olma tüm canlıların ortak özelliğidir, Dışarıdan beslenme tüm canlıların ortak özelliğidir, Hayvanlar yer değiştirerek hareket etmez, Kuşlar yavrularını sütle besler ve Kuşlar doğurarak çoğalır gibi Canlıların Sınıflandırılması konusu ile ilgili kavram yanılgıları da tespit edilmiştir. Tüm bu sonuçlar "Canlılar Dünyasını Gezelim ve Tanıyalım” ünitesi ile ilgili ortaokul beşinci sınıf öğrencilerinin çok sayıda kavram yanılgısına sahip olduğunu göstermektedir. Bu nedenle, öğrencilerin bilimsel bilgiyi doğru şekilde algılayıp, zihinlerinde yapılandırabilecekleri ders tasarımlarının yapılması son derece önemlidir. Öğretmenlerin bu durumu biliyor olmaları ve derslerini planlarken bu noktalara dikkat etmeleri sayesinde, öğrencilerin bilgiyi doğru yapılandırmaları ve bu sayede de kavram yanılgılarının oluşmaması sağlanacaktır.

\section{Öneriler}

- Öğrencilerin sahip olduğu kavram yanılgılarının belirlenmesinde, öğrenci verdiği cevabın nedenini de açıklama şansına sahip olduğu için üç aşamalı testlere başvurulmalıdır.

- Fen eğitimcileri öğrencilerin bilgiyi daha doğru şekilde yapılandırabilecekleri öğrenme ortamlarını hazırlamalı, tasarımlar yapmalıdır. 
- Eğitimcilerin, çalışmada tespit edilen kavram yanılgılarını dikkate alarak derslerini tasarlamaları, öğrencilerin kavram yanılgılarının azalmasında etkili olacaktır.

\section{Makalenin Bilimdeki Konumu}

Matematik ve Fen Bilimleri Eğitimi Bölümü/Fen Bilgisi Eğitimi

\section{Makalenin Bilimdeki Özgünlüğ̈̈}

Literatürde kavram yanılgıları konusunda çok sayıda çalışmaya rastlanmaktadır. Ancak ortaokul 5.sınıf öğrencilerinin Fen Bilimleri dersi Canlıların Sınıflandırılması ve Çevre sorunları konularında sahip olduğu kavram yanılgılarına yönelik yeterli çalışmanın yer almadığı tespit edilmiştir. Aynı zamanda öğrencilerin ilgili konularda sahip oldukları kavram yanılgılarının tespit edilmesinde üç aşamalı testlerin kullanımına yönelik çalışmalar da yeterli düzeyde değildir. Bu nedenle ortaokul beşinci sınıf öğrencilerinin "Canlılar Dünyasını Gezelim ve Tanıyalım” ünitesine yönelik kavram yanılgıları üç aşamalı test ve yarı yapılandırılmış görüşmelerle araştırılmıştır.

\section{Kaynaklar}

Allen, M. (2010). Misconceptions in primary science. Berkshire: Open University Press.

Altın, K. ve Aslan, M. (2006). Kavram haritalarının fizik dersinde kavram yanılgılarının belirlenmesinde kullanılması. Yedi Tepe Üniversitesi Eğitim Fakültesi Dergisi EDU7, 1 (2). Erişim adresi: http://journal.yeditepe.edu.tr/index.php/edu7/article/view/14

Anıl, Ö. ve Küçüközer, H. (2010). Ortaöğretim 9. sınıf öğrencilerinin düzlem ayna konusunda sahip oldukları ön bilgi ve kavram yanılgılarının belirlenmesi. Türk Fen Eğitimi Dergisi, 7 (3), 104-122.

Arsal, Z. (2010). İlköğretim öğretmen adaylarının sera etkisi ile ilgili kavram yanılgıları. Ilkögretim Online, 9 (1), 229-240.

Arslan, H. O., Ciğdemoglu, C. \&Moseley, C. (2012). A three-tier diagnostic test to assess preservice teachers' misconceptions about global warming, green house effect, ozon elayer depletion, and acid rain. International Journal of Science Education, 34 (11), 16671686. doi:10.1080/09500693.2012.680618

Ausubel, D. P. (1968). Educational psychology: A cognitive view, New York: Holt, Rinehart and Winston.

Aydoğan, Ş. ve Köksal, E. A. (2017). İlköğretim fen eğitiminde kavram yanılgıları konusunda yapılan çalışmaların içerik analizi. Eğitimde Kuram ve Uygulama, 13 (2), 232-260. 
Aymen Peker, E. ve Taş, E. (2019). Üç aşamalı kavram tanı testi geliştirme ve geçerlik çalışması: 5. sınıf canlılar dünyasını gezelim tanıyalım ünitesi. Journal of Computer and Education Research, 7(14), 515-539. DOI: 10.18009/jcer.602223.

Bacanak, A., Küçük, M. ve Çepni, S. (2004). İlköğretim öğrencilerinin fotosentez ve solunum konularındaki kavram yanılgılarının belirlenmesi: Trabzon örneklemi. Ondokuz Mayıs Üniversitesi Ĕ̈itim Fakültesi Dergisi, 17, 67-80.

Başoğlu, S. (2017). Klasik ve teknoloji destekli tanılayıcı dallanmış ăgaç tekniğinin öğrencilerin akademik başarılarına, kavram yanılgılarına ve bilişsel yüklerine etkisi (Yayımlanmamış Yüksek Lisans Tezi). Ordu Üniversitesi Fen Bilimleri Enstitüsü, Ordu.

Baysarı, E. (2007). Illköğretim düzeyinde 5. sinıf Fen ve Teknoloji dersi Canlılar ve Hayat ünitesi öğretiminde kavram karikatürü kullanımının öğrenci başarısına, fen tutumuna ve kavram yanılgılarının giderilmesine olan etkisi (Yayımlanmamış yüksek lisans tezi). Dokuz Eylül Üniversitesi Eğitim Bilimleri Enstitüsü, İzmir.

Bolat, A., Aydoğdu, R.Ü., Uluçınar Sağır, Ş. ve Değirmenci, S. (2014). 5. sınıf öğrencilerinin güneş, dünya ve ay kavramları hakkındaki kavram yanılgılarının tespit edilmesi. Eğitim ve Öğretim Araştırmaları Dergisi, 3 (1), 218-229.

Braund, M. (2010). Children's ideas in classifying animals. Journal of Biological Education, 25 (2), 103-110.

Buluş Kırıkkaya, E. ve Güllü, D. (2008). Fifth grade students' misconceptions about heat temperature and evaporation- boiling. Elementary Education Online, 7 (1), 15-27.

Caner, S. (2008). Canlıların sinıflandırılması konusunda bilgisayar destekli materyal geliştirilerek 5 E modeline uygulanması ve kavram yanılgılarını gidermedeki etkinliği (Yayımlanmamış Yüksek Lisans Tezi). Balıkesir Üniversitesi Fen Bilimleri Enstitüsü, Balıkesir.

Creswell, J. W. (2003). Research design: Qualitative, quantitative, and mixed methods approaches (2nd ed.). Thousand Oaks, CA: Sage Publications.

Creswell, J.W. \&Plano Clark, V.L. (2015). Karma yöntem araştırmaları tasarımı ve yürütülmesi. Y. Dede \& S. B. Demir (Çeviri Ed.). Ankara: Anı Yayıncılık.

Çardak, O. (2002). Lise birinci sınıf öğrencilerinin canlıların çeşitliliği ve sınıflandırılması ünitesindeki kavram yanılgllarının tespiti ve kavram haritaları ile giderilmesi (Yayımlanmamış Doktora Tezi). Selçuk Üniversitesi Fen Bilimleri Enstitüsü, Konya. 
Çetinkaya, M. (2010). Canlıların sınıflandırılması konusu için web destekli kavram haritaları ve anlam çözümleme tablolarının öğrenme üzerindeki etkisinin araştırılması (Yayımlanmamış yüksek lisans tezi). Ondokuz Mayıs Üniversitesi Fen Bilimleri Enstitüsü, Samsun.

Çıldır, I., ve Şen, A.İ. (2006) Lise öğrencilerinin elektrik akımı konusundaki kavram yanılgılarının kavram haritalarıyla belirlenmesi. Hacettepe Üniversitesi Ĕ̈itim Fakültesi Dergisi, 30, 92-101.

Çinici, A. (2011). Lise öğrencilerinin hayvanların sınıflandırılması ile ilgili alternatif kavramları: Omurgalı hayvanlar. Türk Fen Eğitimi Dergisi, 8 (4), 171-187.

Demir, A. ve Sezek, F. (2009). İlköğretim sekizinci sınıf fen ve teknoloji dersi genetik ünitesindeki kavram yanılgılarının giderilmesinde grafik materyallerinin etkisi. Uluda $\breve{g}$ Üniversitesi Eğitim Fakültesi Dergisi, 2 (12), 573-587.

Demirci, N. ve Efe, S. (2007). İlköğretim öğrencilerinin ses konusundaki kavram yanılgılarının belirlenmesi. Necatibey Ĕ̈itim Fakültesi Elektronik Fen ve Matematik Eğitimi Dergisi(EFMED), 1 (1), 23-56.

Derman, İ. (2019). Fen bilimleri dersinin yaşamla ilişkilendirilme düzeyi (Yayımlanmamış Doktora Tezi). Hacettepe Üniversitesi Eğitim Bilimleri Enstitüsü, Ankara.

Dikmenli, M., Türkmen, L. ve Çardak, O. (2002). İlköğretim öğrencilerinin "Hayvanlar alemi ve sınıflandırılması" kavramlarılla ilgili alternatif görüşleri. 5. Ulusal Fen Bilimleri ve Matematik Eğitimi Kongresi bildiri kitabı. Ankara: ODTÜ. Erişim adresi: http://old.fedu.metu.edu.tr/ufbmek-5/b_kitabi/PDF/Biyoloji/bildiri/t17d.pdf

Ercan, F., Taşdere, A. ve Ercan, N. (2010). Kelime ilişkilendirme testi aracıllğıyla bilişsel yapının ve kavramsal değişimin gözlenmesi. Türk Fen Eğitimi Dergisi, 7 (2), 136-154.

Eryılmaz, A. ve Sürmeli, E. (2002). Üç-aşamalı sorularla ögrrencilerin ısı ve sıcaklık konularındaki kavram yanılgılarının ölçülmesi. 5. Ulusal Fen Bilimleri ve Matematik eğitimi kongresi. Ankara: ODTÜ. Erişim adresi: http://old.fedu.metu.edu.tr/ufbmek5/b kitabi/PDF/Fizik/Bildiri/t110d.pdf

Kaptan, F. (1999). Fen bilgisi öğretimi. İstanbul: Milli Eğitim Basımevi

Karakuyu, Y. ve Tüysüz, C. (2011). Elektrik konusunda kavram yanılgıları ve kavramsal değişim yaklaşımı. Gaziantep Üniversitesi Sosyal Bilimler Dergisi, 10 (2), 867-890.

Karataş F.Ö., Köse S. ve Coştu, B., (2003). Öğrenci yanılgılarını ve anlama düzeylerini belirlemede kullanılan iki aşamalı testler. Pamukkale Ĕgitim Fakültesi Dergisi, 1(13), 54-69. 
ISSN: 1305-2020

Köse S., Coştu, B. ve Keser, Ö. F., (2003). Fen konularındaki kavram yanılgılarının belirlenmesi: TGA yöntemi ve örnek etkinlikler. Pamukkale Eğitim Fakültesi Dergisi, $1(13), 43-53$.

Köse, S. \& Uşak, M. (2006). Determination of prospective science teachers' misconceptions: Photosynthesis and respiration in plants. International Journal of Environmental and Science Education 1(1), 25-52.

Malatyal1, E. \& Y1lmaz, K. (2010). The importance of concepts in the constructivist learning process: an Examination of concepts from pedagogicalangle, The Journal of International Social Research, 3(14), 320-332.

Meşeci, B., Tekin, S. ve Karamustafaoğlu, S. (2013). Maddenin tanecikli yapısıyla ilgili kavram yanılgılarının tespiti. Dicle Üniversitesi Sosyal Bilimler Enstitüsü Dergisi, 5 (9), 20-40.

Milli Eğitim Bakanlığı (MEB) (2013). İlköğretim kurumları (İlkokullar ve Ortaokullar) Fen bilimleri dersi (3,4,5,6,7 ve 8. sinıflar) ögretim programı. Ankara: MEB Talim ve Terbiye Kurulu Başkanlığı.

Milli Eğitim Bakanlığı (MEB) (2018). Fen bilimleri dersi ögretim programı (Illkokul ve Ortaokul 3,4,5,6,7 ve 8. sinıflar). Ankara: MEB Talim ve Terbiye Kurulu Başkanlı̆̆ı.

Mutlu, M. ve Tokcan, H. (2012). İlköğretim 7. sınıf öğrencilerinin toprak kirliliği hakkındaki düşünceleri. International Journal of Social Science Research, 1 (1), 65-75.

Nakiboğlu, C. ve Arık, R. Ö. (2006). 4. sınıf öğrencilerinin “Gazlar” ile ilgili kavram yanılgılarının V-diyagramı kullanılarak belirlenmesi. Yedi Tepe Üniversitesi Ĕ̌itim Fakültesi Dergisi, EDU7, 1 (2), 1-17.

Novak, J. D. (1998). Learning, creating and using knowledge: concept maps as facilitative tools in schools and corporations, Mahwah, NJ: Lawrence Erlbaum.

Özdemir, A. M. (2012). İlköğretim 5. sınıffen ve teknoloji dersi ünitelerinde kavramsal değişim yaklaşımının öğrenci başarısına etkisinin incelenmesi (Yayımlanmamış Doktora Tezi). Gazi Üniversitesi Eğitim Bilimleri Enstitüsü, Ankara.

Özdemir, G., ve Çalışkan, İ. (2018). Ortaokul 5. ve 6. sınıf öğrencilerinin "omurgalı ve omurgasız hayvanların sınıflandırılması” konusuna ilişkin kavram yanılgıları. Elementary Education Online, 17 (2), 658-674.

Özyılmaz Akamca, G. (2008). İlköğretimde analojiler, kavram karikatürleri ve tahmin-gözlemaçıklama teknikleriyle desteklenmiş fen ve teknoloji eğitiminin öğrenme ürünlerine etkisi (Yayımlanmamış doktora tezi). Dokuz Eylül Üniversitesi Eğitim Bilimleri Enstitüsü, İzmir. 
Peşman, H. \& Eryılmaz, A. (2010). Development of a three-tier test to assess misconceptions about simple electric circuits. Journal of EducationalResearch, 103 (3), 208-222. doi: $10.1080 / 00220670903383002$

Richardson,V. (2003). Constructivist pedagogy, Teachers College Record,105 (9),1623-1640.

Roth, W.M. \& Roychoughury, A. (1992). The social of struction of scientific concept or the concept map as conscription device and tool for social thinking in high school science. Science Education, 76 (5), 531-557.

Saka, A., Ayas, A. ve Enginar, İ. (2002). Öğrencilerin omurgalı-omurgasız canlılar ile ilgili görüşlerinin yaşlara göre değişimi. 5. Ulusal Fen Bilimleri ve Matematik Eğitimi Kongresi. Eylül, Ankara: ODTÜ.

Sivrikaya, E., (2005). Canlıların çeşitliliği ve sınıflandırılması ünitesine yönelik kavramsal değişim metinlerinin, başarıya etkisi (Yayımlanmamış Yüksek Lisans Tezi). KTÜ Fen Bilimleri Enstitüsü, Trabzon.

Summers, M., Kruger, C., Childs, A. \&Mant, J. (2000). Primary school teachers' understanding of environmental issues: An interview study. Environmental Education Research, 6 (4), 293-312.

Şaşmaz Ören, F., Karatekin, P., Erdem, Ş. ve Ormanc1, Ü. (2012). Öğretmen adaylarının bitkilerde solunum-fotosentez konusundaki bilgi düzeylerinin kavram karikatürleriyle belirlenmesi ve farklı değişkenlere göre analizi. Ahi Evran Üniversitesi Kırşehir Ĕ̆itim Fakültesi Dergisi, 13 (3), 155-174.

Tashakkori, A., \&Teddlie, C. (1998). Mixed methodology: combining qualitative and quantitative approaches (46.ed.). Thousand Oaks, CA: Sage Publications.

Taş, E., Aymen Peker, E. \& Çetinkaya, M. (2014). Determining of misconceptions by means of three-tier test about the unit human and environment. Proceedings of 2 nd International Conference on Economics and SocialSciences, 85-90.

Tekkaya, C., Çapa, Y. ve Yılmaz, Ö. (2000). Biyoloji öğretmen adaylarının genel biyoloji konularındaki kavram yanılgıları. Hacettepe Üniversitesi Eğitim Fakültesi Dergisi, 18, 140- 147.

Tortop, H.S., Çiçek Bezir, N., Uzunkavak, M., ve Özek, N. (2007). Dalgalar laboratuvarında, kavram yanılgılarını belirlemek için V-diyagramlarının kullanımı ve derse karşı geliştirilen tutuma olan etkisi. Süleyman Demirel Üniversitesi Fen bilimleri Enstitüsü Dergisi, 11 (2), 100-115.

Türk Dil Kurumu (TDK), 2018. Erişim adresi (15.01.2018) https://sozluk.gov.tr/?kelime= 
Türkmen, L.,Çardak, O.,Dikmenli, M.,(2005). Lise-1 Biyoloji dersi alan öğrencilerin canlıların çeşitliliği ve sınıflandırılmasıyla ilgili kavram yanılgılarının belirlenmesi ve kavram haritası yardımıyla değiştirilmesi, Gazi Eğitim Fakültesi Dergisi, 25(1), 155-168.

Uyanık, G. ve Dindar, H. (2016). İlkokul dördüncü sınıf fen bilimleri dersinde kavramsal değişim metinlerinin kavram yanılgılarının giderilmesine etkisi. Gazi Eğitim Fakültesi Dergisi, 36 (2), 349-374.

Ülgen, G. (2001). Kavram geliştirme, Ankara: Pegem A Yayıncılık.

Ürey, M., Şahin, B. ve Şahin, F. (2011). Öğretmen adaylarının temel ekoloji kavramları ve çevre sorunları konusundaki yanılgıları, Ege Eğitim Dergisi, 12 (1), 22-51.

Yağbasan, R. ve Gülçiçek, Ç. (2003). Fen öğretiminde kavram yanılgılarının karakteristiklerinin tanımlanması. Pamukkale Üniversitesi Ĕ̆itim Fakültesi Dergisi, 13, 102-120.

Yen, C-F., Yao, T-W. \&Mintzes, J-J. (2007). Taiwanesestudents' alternativeconceptions of animalbiodiversity. International Journal of ScienceEducation. 29 (4), 535-553. doi: 10.1080/09500690601073418. 


\section{Summary}

\section{Statement of Problem}

Concept is abstract and general design of an object or an idea in the mind (TDK, 2018). In other words, the concept is an abstract unit of thought in which people visualize objects and ideas in their minds (Ülgen,2001; Yağbasan \& Gülçiçek, 2003).

One of the main objectives of science education is to enable students understand the concepts in science and apply it. Therefore, it is important to reveal the concepts that students have about the subject before teaching science topics (Yağbasan \& Gülçiçek, 2003).

When the science course gains are examined, it is observed that it contains both concrete and abstract concepts (Ministry of Education; 2013, 2018). Some researches reveal that abstract concepts are not fully understood by students. (Bell, 1985; Marek, 1986; Osborne \& Cosgrove, 1983, retrieved from Bacanak et al, 2004).

Depending on reasons such as the student's daily life and experiences, beliefs, learning environments, undeveloped mental skills and efforts to make sense of the concepts, the concept in the student's mind conflicts with the nature of science and scientific knowledge. The student assigns false meanings to scientific knowledge, in this process. Such non-scientific interpretation process is explained by the term misconception. (Ercan, Taşdere \& Ercan, 2010).

Many methods are used to determine students' misconceptions. Although achievement test is a frequently used method, it is not sufficient to determine misconceptions. Because if the student explains his / her own misconceptions and states that he / she is sure of his / her answer, it can be said that the student has misconceptions (Demirci \& Efe, 2007; Eryılmaz \& Sürmeli, 2002; Karataş, Köse \& Coştu, 2003). Although there are researches conducted in order to determine students' misconceptions in science subjects, researches on misconceptions of fifth grade students about the "Let's Travel and Learn about the Living World" unit is insufficient after the 2013 curriculum change. Based on this deficiency, this research was conducted to determine the answer to the question of What kind of misconceptions the fifth-grade students have about the " Let's Travel and Learn about the Living World " unit. 


\section{Method}

In this research, qualitative and quantitative research methods were used together. Qualitative data were obtained through semi-structured interviews, while the 23-item three-tier concept achievement test was used to obtain quantitative data. 226 secondary school 5 th grade students which from three different schools participated in the study conducted in Samsun in the 2014-2015 academic years.

In the three-tier test, the response to each tier of the question was considered. By using the macro application developed in MS Excel program, findings have been reached in four categories: misconceptions, scientific knowledge, lucky answer and lack of knowledge.

In addition, in order to determine students' misconceptions, semi-structured interviews were conducted with the students after the unit was processed. The data obtained from the interviews were analyzed descriptively.

\section{Findings}

When Table 3 is examined, it is seen that the students' correct answer rate of question items is higher when the question is evaluated as a single item. Percentage of misconceptions in questions 5., 7., 9., 16. and 23. on the subject of "Let's Know Living Things" and 10, 13, 14, 15, 20 and 22 on subject of "Human and Environment" is over 20. (Table 3).

Twelve questions which were found to be misconceptions were examined in detail. Data tables showing the response frequencies of the students were obtained. The data are presented in Table 4 to Table 15 respectively. At the end of each table, students' misconceptions about the related question were listed.

When the data obtained from semi-structured interviews with forty-nine students were analyzed descriptively, it was observed that twenty-six students had the misconception after the learning process. It was observed that the students expressed some misconceptions determined in the three-tier test in the interview. Such as Bat is a bird (Table 11), Snake is not a vertebrate, The butterfly is not a vertebrate because there is no bone in it. (Table 15).

\section{Discussion and Conclusion}

In this study, students' misconceptions about the "Let's Travel and Learn about the Living World" unit within the "Creatures and life" learning area were determined through threetier concept achievement test and semi-structured interviews after processing the unit. As a result of the research, it was determined that the students had a total of forty-one misconceptions 
related to the twelve questions in the concept achievement test consisting of twenty-three questions.

Some of the misconceptions detected are the same as the misconceptions found in previous studies Başoğlu (2017), Braund, 2010, Caner (2008), Çardak, 2002, Çetinkaya, 2010, Çinici, 2011, Dikmenli et all., 2002, ÖzdemirveÇalışkan (2018), ÖzyılmazAkamca, 2008, Saka et all., 2002, Tekkaya et all, 2000 and Ural Keleş (2009)). Some of the misconceptions are related to misconceptions previously identified by some researchers (Baysar1, 2007, Caner, 2008, Ürey et all., 2011, Yen et all., 2007). As a result of the research, twenty misconceptions about Human-Environment Relationship subject and twenty misconceptions about the Classification of living things subject have been determined. Some of these misconceptions are different previously identified in the literature. 